\title{
Effects of Exogenous Application of Plant Growth Regulators on Growth, Yield, and In Vitro Gynogenesis in Cucumber
}

\author{
Piyada Alisha Tantasawat ${ }^{1}$, Atitaya Sorntip, and Paniti Pornbungkerd \\ School of Crop Production Technology, Suranaree University of Technology, \\ 111 University Avenue, Muang District, Nakhon Ratchasima 30000, \\ Thailand
}

Additional index words. callus, embryo-like structure, ELS, hormone, unpollinated ovary culture

\begin{abstract}
The effects of exogenous application of plant growth regulators (PGRs) were evaluated on both field performance and in vitro gynogenesis of ' $C$ hai Lai' and ' $B i g$ ' cucumber (Cucumis sativus L.). Plants were sprayed with two concentrations of $\mathrm{N}^{6}$ furfuryladenine [kinetin (KIN); 2 and 20 ppm], 2,3,5-triiodobenzoic acid (TIBA; 1 and 10 ppm), naphthaleneacetic acid (NAA; 10 and 100 ppm), abscisic acid (ABA; 2 and 20 ppm), thidiazuron (TDZ; 1 and 10 ppm), and maleic hydrazide (MH; 10 and $100 \mathrm{ppm}$ ) to assess their effects on vegetative growth and floral and yield related traits in the Winter of 2013 and in the Summer of 2014 compared with distilled water control. Meanwhile, the effects of two PGRs (KIN and TIBA) on cucumber gynogenesis were also investigated in vitro. Growth parameters and floral and yield-related traits were significantly affected by the various PGRs in both cultivars during both seasons. In both cultivars, the highest yield was obtained with the application of $10 \mathrm{ppm}$ NAA during the Winter of 2013 (1.5- to 1.8-fold over control) and with 1 ppm TIBA during the Summer of 2014 (2.1- to 2.2-fold over control). With regard to the ovary culture response, exogenous application of KIN and TIBA on floral buds tended to enhance callus formation in 'Chai Lai' cultured on I7 medium, whereas no effect was observed in 'Big C'. The embryo-like structure (ELS) formation efficiencies also tended to increase with 2 and $20 \mathrm{ppm}$ KIN and 1 ppm TIBA application in 'Chai Lai' and with 20 ppm KIN and 1 ppm TIBA application in 'Big C' when cultured on $I 7$ medium. Nevertheless, TIBA at high concentrations (10 ppm) decreased the percentages of ELS formation and the number of ELSs/piece in both cultivars. These results suggest that the polar auxin transport may play a major role on growth, floral and yield-related traits, yield as well as in vitro gynogenesis in cucumber. However, the success of exogenous applications of these PGRs depended on several factors including plant genotypes, growing seasons, types and concentrations of PGRs, and for ovary culture, the responses also varied according to the induction media used. Chemical names: abscisic acid (ABA); maleic hydrazide (MH); naphthaleneacetic acid (NAA); $\mathbf{N}^{6}-$ furfuryladenine (kinetin; KIN); thidiazuron (TDZ); 2,3,5-triiodobenzoic acid (TIBA).
\end{abstract}

Cucumber (Cucumis sativus L.) is one of the most important economic cucurbits, cultivated more broadly than any other vegetable species (Staub et al., 2008). In 2012, more than 65 million metric tonnes of cucumbers were produced worldwide. In Thailand cucumber production reached $265,000 \mathrm{t}$ from total cultivated area of 25,000 ha. It is widely used for fresh and processed consumption as

Received for publication 2 Oct. 2014. Accepted for publication 19 Dec. 2014

This research was partially supported by the Higher Education Research Promotion and National Research University Project of Thailand, Office of the Higher Education Commission, Ministry of Education, and grants from Suranaree University of Technology, Thailand.

We are very grateful to Peter Charles Bint for the critical reading of this manuscript.

${ }^{1}$ To whom reprint requests should be addressed; e-mailpiyada@sut.ac.th. the number of pistillate flowers, number of fruits/plant, and individual fruit weight as well as yield (Mia et al., 2014). In cucumber, Papadopoulos et al. (2006) reported that a 2.5-ppm KIN foliar spray had beneficial effects on plant growth (taller plants, greater leaf area, and fresh weight of leaves and stems), resulting in higher marketable yield in the spring-summer crop and in larger fruit size in the fall-winter crop. Rahman (1970) evaluated the effects of PGRs on modifications of flowering, sex expression, and fruiting of cucurbits, and found that MH, NAA, TIBA, and IAA inhibited vegetative growth, suppressed staminate and enhanced pistillate flower formation in cucumber. Early and total yields were increased by applications of 100 ppm of MH, NAA, or IAA at the four-leaf stage. Jadav et al. (2010) conducted an experiment where the various PGRs, viz., NAA (100 and $200 \mathrm{ppm}), \mathrm{GA}_{3}$ (10 and $20 \mathrm{ppm}), \mathrm{ABA}$ (10 and $20 \mathrm{ppm}), \mathrm{KIN}$ (10 and $20 \mathrm{ppm}$ ), and ethrel (200 and $300 \mathrm{ppm}$ ), were used for conversion from staminate flowers to pistillate flowers. Yield investigation revealed that the PGRs at all concentrations significantly increased the number of fruits/ plant. However, the effects of PGRs are often genotype-dependent and may be environmentally variable (Rahman, 1970), requiring specific evaluations for individual cultivars in different environments.

New hybrid cucumber cultivars with high yield and disease resistance are constantly in demand, necessitating the production of inbred lines to be used as parents in breeding programs. These inbred lines can be generated either through selfing or doubled haploid (DH) production. The leading processes for production of DH cucumbers are parthenogenesis (induced by pollination with irradiated pollen), androgenesis (in vitro culture of microspores and anthers), and gynogenesis (in vitro culture of ovules and ovaries) (Chen et al., 2011; Germaná, 2011). Many researchers have successfully generated haploid $(\mathrm{H})$ and DH cucumbers through ovary/ ovule culture (Gémesné Juhász et al., 1997, 2002; Moqbeli et al., 2013). By this method, $\mathrm{H} / \mathrm{DH}$ plants are regenerated through either the formation of ELSs directly on ovules or the formation of ELSs or shoots on calli induced from ovules or ovaries (Bhojwani and Razdan, 1996; Reed, 2005). In Thailand, the gynogenesis induction of H/DH cucumbers is still limited and plant regeneration has not been observed from ovule-derived calli of Thai cucumber cultivars (Sampaokaew et al., 2009). Previously, we evaluated factors influencing the induction of ELSs and calli in unpollinated ovary culture of five Thai cucumber cultivars and found that donor plant genotypes and induction media, differing in PGRs, affected both ELS and callus formation. The addition of TDZ and 6-benzylaminopurine (BAP) into the induction medium resulted in the highest percentage of ELS formation (Tantasawat et al., 2015). Similarly, the addition of TDZ increased embryogenesis success in ovary/ovule culture in other studies (Li et al., 2013; Moqbeli et al., 2013; 
Suprunova and Shmykova, 2008). TDZ exhibits both auxin and cytokinin-like effects, whereas BAP shows a cytokinin-like effect and polar auxin transport inhibitor (Guo et al., 2011; Smulders et al., 1998; Teixeira da Silva, 2012). These results suggest that cytokinin and/or auxin plays a major role on ELS formation. During plant tissue culture, it was reported that auxin affects the polar transport and plays a central role in plant embryogenesis, whereas cytokinin plays a major role in cell division and cell differentiation, inducing organogenesis (Barciszewski et al., 2000; Cooke et al., 1993). Because the gynogenesis response in cucumber appeared to be seasonally variable (P.A. Tantasawat et al., unpublished data), it is possible that the endogenous phytohormone levels in donor plant tissues, which were environment-dependent, may also play a crucial role during the gynogenesis process. Although the effects of various cytokinins and auxins have been assessed in vitro by adding these PGRs directly into the culture media, the effects of the exogenous application of PGRs on donor plant tissues before ovary/ovule culture of cucumber have not been evaluated. We hypothesize that the application of PGRs on the pistillate flowers since an early stage may enhance the gynogenesis process, thereby increasing the percentages of ELS/callus formation and improving the efficiency of cucumber DH production

In this study, we evaluated the effects of exogenous application of various PGRs including KIN, TIBA, NAA, ABA, TDZ, and $\mathrm{MH}$ on vegetative growth, floral and yield-related traits, and yield of two Thai cucumber cultivars in two growing seasons. Moreover, the effects of two of these PGRs (KIN and TIBA) on cucumber in vitro gynogenesis were also investigated.

\section{Materials and Methods}

Plant materials. Two Thai cultivars of cucumber, a hybrid gynoecious 'Chai Lai' (Chia Tai Co., Ltd., Bangkok, Thailand) and a hybrid monoecious 'Big C' (East-West Seed Co., Ltd., Nonthaburi, Thailand), were used. For evaluation of vegetative growth, floral and yield-related traits, and yield, plants were grown in the Suranaree University of Technology Farm, Nakhon Ratchasima, Thailand, during the Winter season (November to December) of 2013 and the Summer season (March to April) of 2014. In the Winter of 2013, the temperature and relative humidity during sowing to crop termination ranged from 14.7 to $28.2{ }^{\circ} \mathrm{C}$ and $29.5 \%$ to $56.5 \%$, respectively. Corresponding temperature and relative humidity ranges for the Summer of 2014 were from 24.6 to $31.8{ }^{\circ} \mathrm{C}$ and $32.6 \%$ to $55.0 \%$, respectively (Fig. 1). An adequate population of pollinators was observed in both seasons. The cucumber seeds were sown at a rate of one seed per hole on the ridge and with a spacing of $125 \times 50 \mathrm{~cm}$. Compound fertilizer $(15 \mathrm{~N}-15 \mathrm{P}-15 \mathrm{~K})$ was applied at an approximate rate of $3.0 \mathrm{~g}$ per vine every
2 weeks after planting. To evaluate the gynogenesis response, plants were grown in $0.5 \times$ 5.5-m cement blocks. The cucumber seeds were sown at a rate of two to three seeds per hole with $20-\mathrm{cm}$ spacing. The first compound fertilizer $(15 \mathrm{~N}-15 \mathrm{P}-15 \mathrm{~K})$ was applied at an approximate rate of $3.0 \mathrm{~g}$ per vine during the first week, and the same rate for the other compound fertilizer $(12 \mathrm{~N}-24 \mathrm{P}-12 \mathrm{~K})$ was used $30 \mathrm{~d}$ after sowing (DAS) and every week after that. The plants were irrigated with a drip system. Weeding and pest control were maintained using standard horticultural practices when needed.

Exogenous application of plant growth regulators. To evaluate growth, floral and yield-related traits, and yield, cucumbers were hand-sprayed with the following treatments: control (distilled water), KIN at 2 and $20 \mathrm{ppm}$, TIBA at 1 and $10 \mathrm{ppm}, \mathrm{NAA}$ at 10 and $100 \mathrm{ppm}, \mathrm{ABA}$ at 2 and $20 \mathrm{ppm}, \mathrm{TDZ}$ at 1 and $10 \mathrm{ppm}$, and $\mathrm{MH}$ at 10 and $100 \mathrm{ppm}$. The first foliar spray of all treatments was given at two to four true-leaf stages until soaking; then the solutions were sprayed every week until the full-bloom stage (at 76 DAS during winter and 60 DAS during summer).

To evaluate the gynogenesis response, a distilled water control and two different PGRs at two concentrations ( 2 and $20 \mathrm{ppm}$ $\mathrm{KIN}$ and 1 and $10 \mathrm{ppm}$ TIBA) were used as treatments. The first spray was given at two true-leaf stage with $250 \mathrm{ppm}$ CEPA to increase the number of pistillate flowers (El-Ghamriny et al., 1988; Meexaewkunchorn, 1995). At the first floral bud appearance, the five treatment solutions were sprayed onto the floral buds until drip. The solutions were sprayed every week until harvesting for the unpollinated ovary culture.

Vegetative growth, floral and yieldrelated traits, and yield measurements. Each experimental treatment contained five or six replicates (one plant/replicate) during winter and summer seasons, respectively. All cucumber fruits were harvested at $9 \pm 2 \mathrm{~d}$ after anthesis. Vegetative growth parameters comprising length of the main stem, number of nodes on the main stem, main stem internode length, number of branches/vine, the average length of branches/vine, number of nodes on branches, and internode length on branches were recorded following Thappa et al. (2011). Floral and yield-related traits including pistillate number, fruit length, fruit diameter, shape index (length/diameter), fruit weight, number of fruits/plant, and fruit yield (fruit weight/plant) were also recorded. The average of these traits was calculated from all cucumber vines and fruits and used for statistical analyses.

Unpollinated ovary culture. Pistillate flowers, $12 \mathrm{~h}$ before anthesis, were obtained from donor cucumber plants, and unpollinated ovaries were sterilized according to Tantasawat et al. (2015). Longitudinal sliced ovaries were placed on three different induction media. All induction media had Murashige and Skoog (Murashige and Skoog, 1962) as basal medium supplemented with $3 \%(\mathrm{w} / \mathrm{v})$ sucrose and solidified with
$0.3 \%(\mathrm{w} / \mathrm{v})$ gelrite. However, they differed in composition of PGRs, glutamine (Gln), casein hydrolyzate $(\mathrm{CH})$, and triacontanol (melissyl alcohol; TRIA): I7 (0.04 mg.L $\mathrm{L}^{-1}$ TDZ) (Diao et al., 2009), I9 (0.04 mg. $\mathrm{L}^{-1}$ TDZ, $0.8 \mathrm{~g} \cdot \mathrm{L}^{-1} \mathrm{Gln}, 0.5 \mathrm{~g} \cdot \mathrm{L}^{-1} \mathrm{CH}$, and $2 \mu \mathrm{L} \cdot \mathrm{L}^{-1}$ TRIA) and $\mathrm{I} 2 \mathrm{G}\left(1 \mathrm{mg} \cdot \mathrm{L}^{-1} \mathrm{TDZ}\right.$, $1 \mathrm{mg} \cdot \mathrm{L}^{-1}$ BAP, $0.8 \mathrm{~g} \cdot \mathrm{L}^{-1} \mathrm{Gln}, 0.5 \mathrm{~g} \cdot \mathrm{L}^{-1} \mathrm{CH}$, and $2 \mu \mathrm{L} \cdot \mathrm{L}^{-1}$ TRIA). The $\mathrm{pH}$ of all induction media was adjusted to 5.7 before autoclaving at $121{ }^{\circ} \mathrm{C}$ for $20 \mathrm{~min}$. Ovaries were kept on induction media in the dark at $25{ }^{\circ} \mathrm{C}$ for 2 weeks and were later cultured at $25{ }^{\circ} \mathrm{C}$ under a 16/8-h (light/dark) photoperiod. After 4 weeks of culture, the percentages of ELS and callus formation were calculated from the number of ovary pieces forming ELSs or calli/total number of ovary pieces multiplied by 100 . Percentage values were transformed with arcsine transformation before statistical analyses.

Experimental design and statistical analyses. A completely randomized design was adopted for all experiments. One-way analysis of variance was used to evaluate the effects of exogenous application of different PGRs. All statistical analyses were performed using SPSS software Version 14 (Levesque and SPSS Inc., 2006). The means were compared by Duncan's multiple range test $(P \leq 0.05)$.

\section{Results and Discussion}

Effects of plant growth regulators on vegetative growth. All vegetative growth parameters were significantly affected by the variously applied PGRs in both seasons. In general, the effects of PGRs were more significant in the Winter of 2013. The results revealed that the high concentration of TDZ $(10 \mathrm{ppm})$ significantly reduced main stem length, main stem internode length, and branch internode length when compared with control in both cultivars in the Winter of 2013. In addition, significant reduction in branch length was also observed with this treatment in 'Chai Lai'. This tendency was also observed in Summer 2014, but only the reductions in the number of nodes on main stem and branch internode length were significant in 'Chai Lai' (Tables 1 and 2). It has been proven that the physiological effect of TDZ is the induction of an early stress response. Some researchers reported that seedlings of several species including legumes and pumpkin exhibited stunted growth in the presence of TDZ. It was also suggested that the action of the mechanism of TDZ can be closely linked to inhibited transportation of IAA (Guo et al., 2011). By contrast, Amarante et al. (2002) reported that TDZ application at $20 \mathrm{ppm}$ significantly increased shoot growth in various apple cultivars.

Similar to the effects of TDZ, it was found that in the Winter of 2013, the high concentration of TIBA (10 ppm) significantly decreased main stem length and main stem internode length in both cultivars and significantly reduced branch length and the number of nodes on branches in 'Chai Lai' (Tables 1 


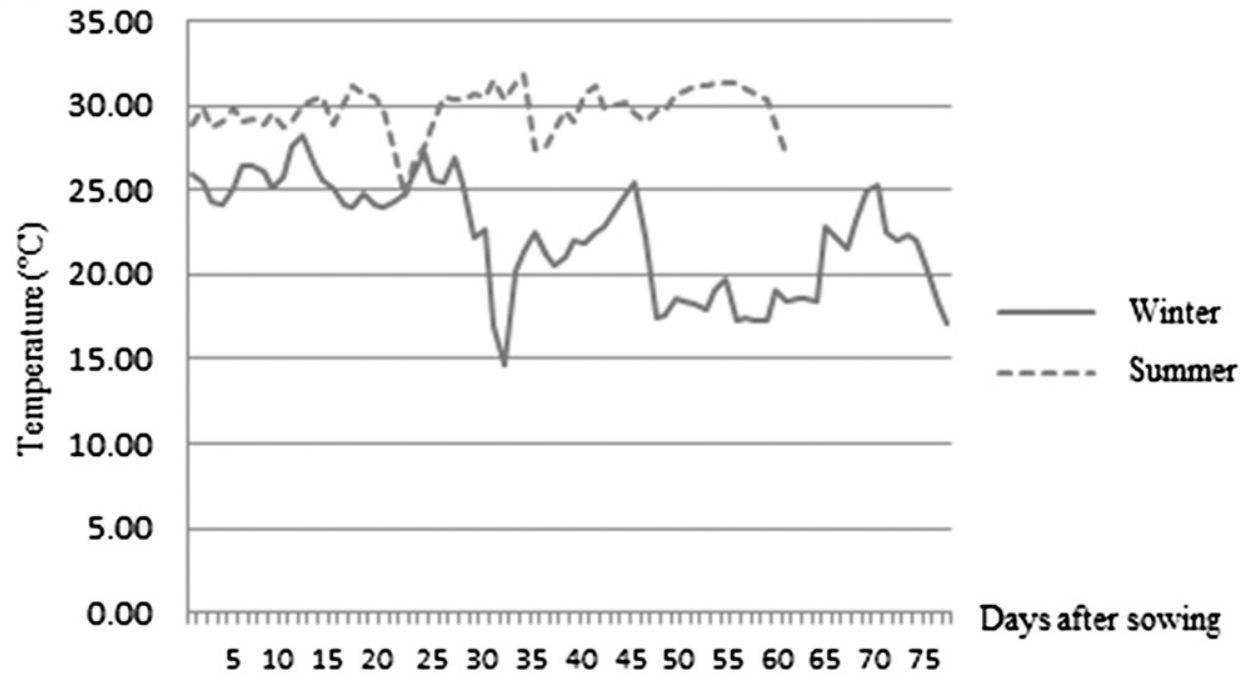

B

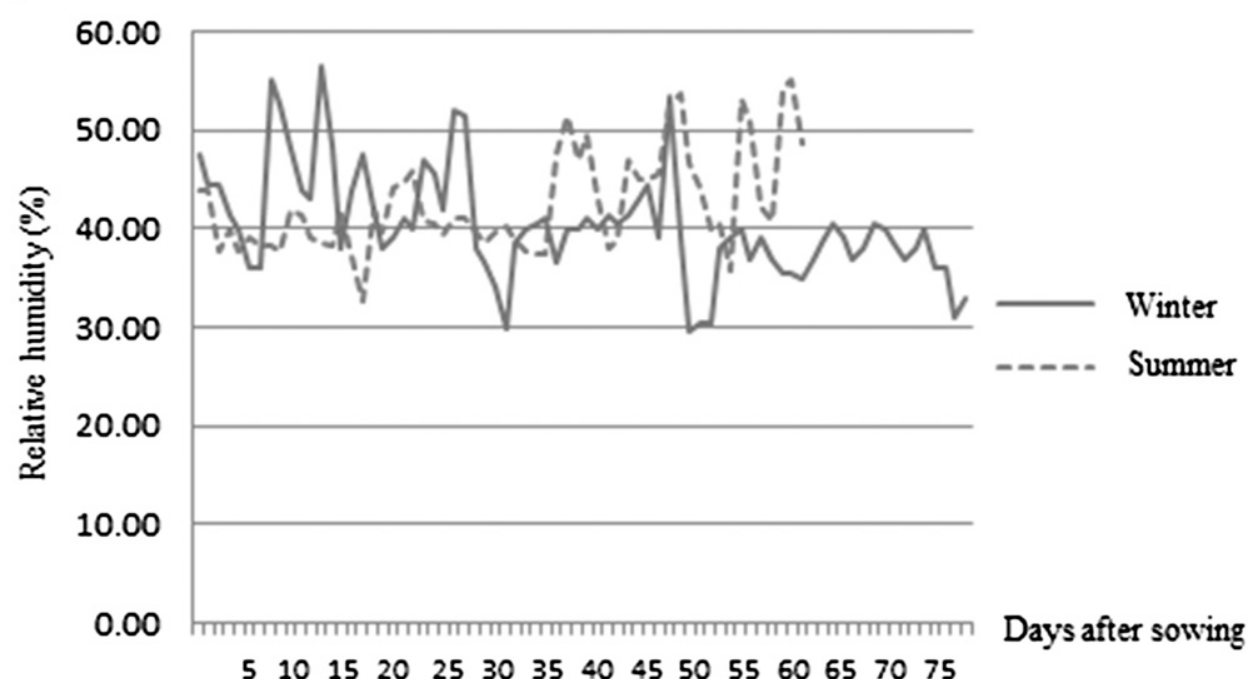

Fig. 1. The weather information data provided by Irrigation Water Management Research Station 3 (Nakhon Ratchasima, Thailand) compared between the Winter (November to December) 2013 and the Summer (March to April) 2014 seasons (A) temperature in Celsius degrees (B) relative humidity in percentage.

and 2). These results were in agreement with Rahman (1970) who reported that TIBA treatment had inhibitory effects on cucumber vegetative growth as they decreased the length of main stem and internodes.

Our results showed that the maximum number of branches was recorded with NAA (100 ppm) in 'Chai Lai' and TIBA $(10 \mathrm{ppm})$ in 'Big $C$ ' during the Winter of 2013. However, during the Summer of 2014, applications of TIBA ( 1 and $10 \mathrm{ppm})$ and NAA $(10 \mathrm{ppm})$ were found to induce the maximum number of branches in 'Chai Lai', but neither induced significantly higher numbers of branches when compared with control in 'Big C' (Tables 1 and 2). This is in contrast to the findings of Rahman (1970) who reported that $50 \mathrm{ppm}$ TIBA reduced the number of branches in cucumber. Nevertheless, in bitter gourd, application of $75 \mathrm{ppm}$ TIBA promoted an increase in the number of branches (Rahman et al., 1992). The inhibited apical growth and increasing numbers of lateral branches may be associated with the polar transport of auxin that is the decisive force of apical dominance. Removal of the tip, the main auxin source, or inhibition of auxin transport leads to the outgrowth of axillary buds (Machakova et al., 2008). This hypothesis was confirmed by our study, namely, that the high concentration of foliar application with TIBA (a polar auxin transport inhibitor) suppressed main stem growth and tended to increase multiple lateral branches in both cultivars and during both growing seasons. Meanwhile, TIBA application at a low concentration had no significant effect on the length of main stems but inclined to increase the number of branches. By contrast, in the Summer of 2014, 100 ppm NAA tended to promote main stem growth but had no significant effect on the number of branches (Tables 1 and 2).

Effects of plant growth regulators on number of pistillate flowers. The sex type of flowers is important for commercial cucumber production because it affects harvest date as well as relative yield. Femaleness and maleness may be altered by environmental factors (i.e., temperature, photoperiod, nutrition, endogenous levels of auxin, gibberellin, ethylene, and $\mathrm{ABA}$ ) or by PGR application (Krishnamoorthy, 1981; Mia et al., 2014). In cucumber, sex differentiation occurs at around the two true-leaf stage and the modification of floral sex can be accomplished at this stage using various PGRs (El-Ghamriny et al., 1988). Our research revealed that application of $1 \mathrm{ppm}$ TIBA in the Summer of 2014 significantly increased the number of pistillate flowers/plant in 'Chai Lai' and also tended to increase the pistillate flower numbers in 'Big C' (Table 4). Similarly, TIBA induced higher numbers of pistillate flowers in cucumber, bottle gourd, cantaloupe, and watermelon (Rahman, 1970; Rahman et al., 1992; Rahman and Thompson, 1969). In our study, NAA application did not significantly affect the number of pistillate flowers, although the increase in pistillate flowers in response to NAA application has been reported in many cucurbits including 
Table 1. The effects of plant growth regulators on vegetative growth in cucumber: the vegetative growth in Winter (November to December) 2013.

\begin{tabular}{|c|c|c|c|c|c|c|c|c|}
\hline $\begin{array}{l}\text { Cucumber } \\
\text { cultivars }\end{array}$ & $\begin{array}{l}\text { Plant } \\
\text { growth } \\
\text { regulators }\end{array}$ & $\begin{array}{l}\text { Length } \\
\text { of main } \\
\text { stem }(\mathrm{cm})\end{array}$ & $\begin{array}{l}\text { Number of } \\
\text { nodes on } \\
\text { main stem }\end{array}$ & $\begin{array}{c}\text { Internode } \\
\text { length of } \\
\text { main stem }(\mathrm{cm})\end{array}$ & $\begin{array}{l}\text { Number of } \\
\text { branches }\end{array}$ & $\begin{array}{c}\text { Length of } \\
\text { branches }(\mathrm{cm})\end{array}$ & $\begin{array}{l}\text { Number of } \\
\text { nodes on } \\
\text { branches }\end{array}$ & $\begin{array}{c}\text { Internode } \\
\text { length of } \\
\text { branches }(\mathrm{cm})\end{array}$ \\
\hline \multirow{10}{*}{ Chai Lai } & Control & $83.26 \pm 5.76^{y} \mathrm{de}$ & $15.80 \pm 0.86 \mathrm{~d}-\mathrm{i}$ & $4.95 \pm 0.19 \mathrm{def}$ & $2.80 \pm 0.37 \mathrm{~cd}$ & $41.48 \pm 5.07 \mathrm{a}-\mathrm{e}$ & $5.37 \pm 0.55 \mathrm{abc}$ & $6.53 \pm 0.31 \mathrm{~b}$ \\
\hline & $\mathrm{KIN}_{2}$ & $75.94 \pm 5.83 \mathrm{efg}$ & $16.00 \pm 1.14 \mathrm{~d}-\mathrm{h}$ & $4.46 \pm 0.13 \mathrm{fgh}$ & $2.80 \pm 0.58 \mathrm{~cd}$ & $31.50 \pm 5.03 \mathrm{c}-\mathrm{g}$ & $4.24 \pm 0.68 \mathrm{a}-\mathrm{d}$ & $6.03 \pm 0.35 b c$ \\
\hline & $\mathrm{TIBA}_{1}$ & $74.52 \pm 4.92 \mathrm{e}-\mathrm{h}$ & $15.00 \pm 0.55 \mathrm{e}-\mathrm{i}$ & $4.64 \pm 0.16 \mathrm{fgh}$ & $3.20 \pm 0.37 \mathrm{bcd}$ & $26.99 \pm 2.21 \mathrm{efg}$ & $3.58 \pm 0.17 \mathrm{bcd}$ & $5.98 \pm 0.42 \mathrm{bc}$ \\
\hline & $\mathrm{TIBA}_{10}$ & $50.28 \pm 2.57 \mathrm{~h}$ & $13.40 \pm 0.68 \mathrm{ghi}$ & $3.51 \pm 0.17 \mathrm{i}$ & $2.80 \pm 0.49 \mathrm{~cd}$ & $22.76 \pm 2.42 \mathrm{fg}$ & $3.55 \pm 0.43 \mathrm{~d}$ & $5.28 \pm 0.42 \mathrm{bcd}$ \\
\hline & $\mathrm{NAA}_{10}$ & $86.84 \pm 5.33 \mathrm{de}$ & $17.80 \pm 0.80 \mathrm{~b}-\mathrm{e}$ & $4.60 \pm 0.11 \mathrm{fgh}$ & $3.20 \pm 0.37 \mathrm{bcd}$ & $41.85 \pm 3.24 \mathrm{a}-\mathrm{e}$ & $6.15 \pm 0.40 \mathrm{a}$ & $5.81 \pm 0.21 \mathrm{bc}$ \\
\hline & $\mathrm{ABA}_{20}$ & $77.30 \pm 6.79$ efg & $16.20 \pm 1.02 \mathrm{c}-\mathrm{g}$ & $4.47 \pm 0.19 \mathrm{fgh}$ & $2.60 \pm 0.51 \mathrm{~cd}$ & $29.99 \pm 6.10 \mathrm{c}-\mathrm{g}$ & $4.27 \pm 0.80 \mathrm{a}-\mathrm{d}$ & $5.52 \pm 0.32 \mathrm{bcd}$ \\
\hline & $\mathrm{TDZ}_{1}$ & $54.44 \pm 4.02 \mathrm{gh}$ & $13.00 \pm 1.18 \mathrm{i}$ & $3.90 \pm 0.08 \mathrm{hi}$ & $2.40 \pm 0.24 \mathrm{~cd}$ & $18.41 \pm 3.49 \mathrm{~g}$ & $2.83 \pm 0.74 \mathrm{~d}$ & $4.88 \pm 0.43 \mathrm{~cd}$ \\
\hline & $\mathrm{TDZ}_{10}$ & $55.92 \pm 3.72 \mathrm{fgh}$ & $13.20 \pm 0.37 \mathrm{hi}$ & $3.92 \pm 0.18 \mathrm{hi}$ & $3.60 \pm 0.40 \mathrm{bcd}$ & $19.84 \pm 2.86 \mathrm{~g}$ & $3.48 \pm 0.56 \mathrm{~cd}$ & $4.41 \pm 0.44 \mathrm{~d}$ \\
\hline & $\mathrm{MH}_{10}$ & $85.68 \pm 6.03 \mathrm{de}$ & $6.80 \pm 1.07 \mathrm{c}-\mathrm{f}$ & $4.80 \pm($ & & $8 \mathrm{~b}-\mathrm{g}$ & $5.10 \pm 1.11 \mathrm{a}-\mathrm{d}$ & $.08 \mathrm{bc}$ \\
\hline & $\mathrm{MH}_{100}$ & $73.28 \pm 3.16 \mathrm{efg}$ & $14.20 \pm 0.58 \mathrm{f}-\mathrm{i}$ & $4.83 \pm 0.19 \mathrm{efg}$ & $2.80 \pm$ & $33.67 \pm 3.89 \mathrm{~b}-\mathrm{g}$ & $4.63 \pm 0.61 \mathrm{a}-\mathrm{d}$ & $6.11 \pm 0.18 b c$ \\
\hline \multirow[t]{8}{*}{ Big C } & Control & $132.24 \pm 15.23 \mathrm{ab}$ & $18.00 \pm 1.18 \mathrm{~b}-\mathrm{e}$ & $6.86 \pm 0.43 \mathrm{ab}$ & & $38.76 \pm 3.70 \mathrm{~b}-\mathrm{e}$ & $3.42 \pm 0.20 \mathrm{~cd}$ & $8.42 \pm 0.36 \mathrm{a}$ \\
\hline & $\mathrm{KIN}_{2}$ & $124.76 \pm 9.13 \mathrm{bc}$ & $18.40 \pm 0.93 \mathrm{bcd}$ & $6.43 \pm($ & $3.00 \pm$ & $47.03 \pm 5$ & $4.50 \pm 0.53 \mathrm{a}-\mathrm{d}$ & $8.84 \pm 0.86 \mathrm{a}$ \\
\hline & & $117.20 \pm 5.48 \mathrm{bc}$ & $17.20 \pm 0.66 \mathrm{~b}-\mathrm{f}$ & $6.43 \pm 0.11 \mathrm{~b}$ & $3.00 \pm 0$. & $31.36 \pm 5.69 \mathrm{c}-\mathrm{g}$ & $2.80 \pm 0.58 \mathrm{~d}$ & $8.18 \pm 0.37 \mathrm{a}$ \\
\hline & $\mathrm{ABA}_{20}$ & $119.90 \pm 14.13 b c$ & $16.80 \pm 1.20 \mathrm{c}-\mathrm{f}$ & $6.65 \pm 0.39 \mathrm{ab}$ & $2.20 \pm 0$. & $51.22 \pm 10.09 \mathrm{ab}$ & $4.97 \pm 1.11 \mathrm{a}-\mathrm{d}$ & $8.57 \pm 0.38 \mathrm{a}$ \\
\hline & $\mathrm{TDZ}_{1}$ & $111.36 \pm 2.35 \mathrm{bc}$ & $17.00 \pm 0.32 \mathrm{~b}-\mathrm{f}$ & $6.19 \pm 0.19 b c$ & $3.40 \pm 0.24 \mathrm{bcd}$ & $37.75 \pm 3.91 \mathrm{~b}-\mathrm{f}$ & $3.42 \pm 0.62 \mathrm{~cd}$ & $8.56 \pm 0.33 \mathrm{a}$ \\
\hline & $\mathrm{TDZ}_{10}$ & $80.82 \pm 3.50 \mathrm{def}$ & $15.00 \pm 0.45 \mathrm{e}-\mathrm{i}$ & $5.05 \pm 0.12 \mathrm{def}$ & $3.60 \pm 0.51 \mathrm{bcd}$ & $28.86 \pm 3.23 \mathrm{~d}-\mathrm{g}$ & $4.59 \pm 0.38 \mathrm{a}-\mathrm{d}$ & $5.13 \pm 0.32 \mathrm{~cd}$ \\
\hline & $\mathrm{MH}_{10}$ & $155.26 \pm 5.28 \mathrm{a}$ & $20.00 \pm 0.55 \mathrm{ab}$ & $7.39 \pm 0.16 \mathrm{a}$ & $3.20 \pm 0.37 \mathrm{bcd}$ & $48.37 \pm 9.41 \mathrm{abc}$ & $4.50 \pm 0.89 \mathrm{a}-\mathrm{d}$ & $8.91 \pm 0.27 \mathrm{a}$ \\
\hline & $\mathrm{MH}_{100}$ & $123.64 \pm 14.06 \mathrm{bc}$ & $17.00 \pm 1.76 \mathrm{~b}-\mathrm{f}$ & $6.88 \pm 0.42 \mathrm{ab}$ & $2.60 \pm 0.24 \mathrm{~cd}$ & $39.57 \pm 9.47 \mathrm{~b}-\mathrm{e}$ & $3.47 \pm 0.85 \mathrm{~cd}$ & $8.47 \pm 0.56 \mathrm{a}$ \\
\hline
\end{tabular}

${ }^{\mathrm{z}}$ The concentration levels of plant growth regulators $(\mathrm{ppm})$ are in subscript. $\mathrm{KIN}=$ kinetin; TIBA $=2,3,5$-triiodobenzoic acid; NAA = naphthaleneacetic acid; $\mathrm{ABA}=$ abscisic acid; $\mathrm{TDZ}=$ thidiazuron; $\mathrm{MH}=$ maleic hydrazide .

${ }^{\mathrm{y}}$ Data are presented as means $\pm \mathrm{SE}$. Data not followed by the same letter in a column are significantly different $(P \leq 0.05)$ based on Duncan's multiple range test.

Table 2. The effects of plant growth regulators on vegetative growth in cucumber: the vegetative growth in Summer (March to April) 2014.

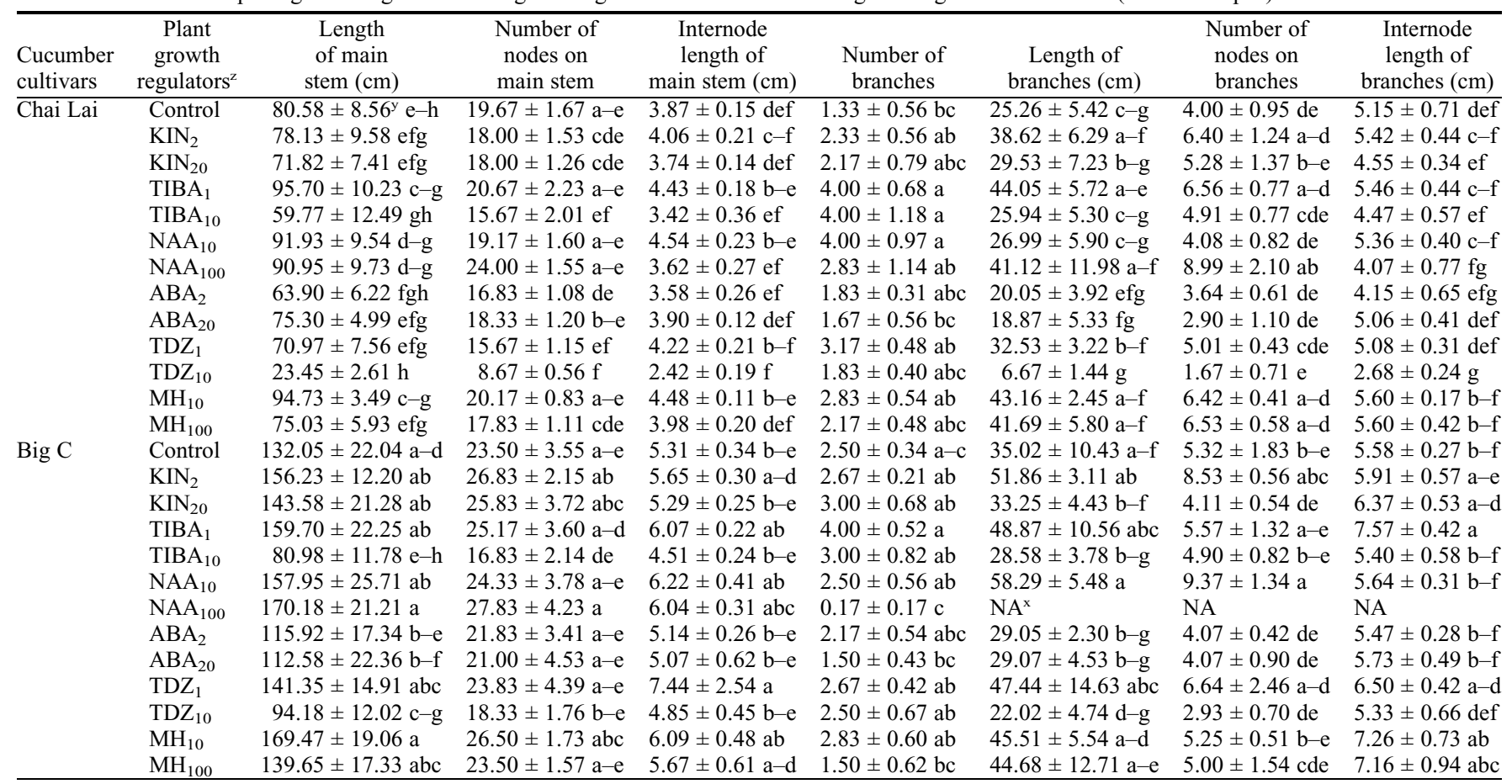

${ }^{\mathrm{z}}$ The concentration levels of plant growth regulators $(\mathrm{ppm})$ are in subscript. KIN = kinetin; TIBA $=2,3,5$-triiodobenzoic acid; NAA $=$ naphthaleneacetic acid; $\mathrm{ABA}=$ abscisic acid; $\mathrm{TDZ}=$ thidiazuron; $\mathrm{MH}=$ maleic hydrazide.

${ }^{y}$ Data are presented as means $\pm \mathrm{SE}$. Data not followed by the same letter in a column are significantly different $(P \leq 0.05)$ based on Duncan's multiple range test. ${ }^{x} \mathrm{NA}=$ not available.

cucumber, bitter gourd, and watermelon (Jadav et al., 2010; Mia et al., 2014; Rahman and Thompson, 1969). In contrast to Choudhury and Singh (1970) and Hidayatullah et al. (2009) who observed an increase in the number of cucumber pistillate flowers/plant with 50 to $200 \mathrm{ppm}$ and $450 \mu \mathrm{M} \mathrm{MH}$ application, respectively, we found that $\mathrm{MH}$ at $10 \mathrm{ppm}$ had no significant effect on pistillate flower numbers in either cucumber cultivar in both seasons, whereas at $100 \mathrm{ppm}$, it lowered the number of pistillate flowers significantly in 'Chai Lai' in the Winter of 2013 (Tables 3 and 4). These results implicated the genotypic and/or environmental influence on sex expression in cucumber. In addition, our results showed a seasonal influence on numbers of pistillate flowers. 


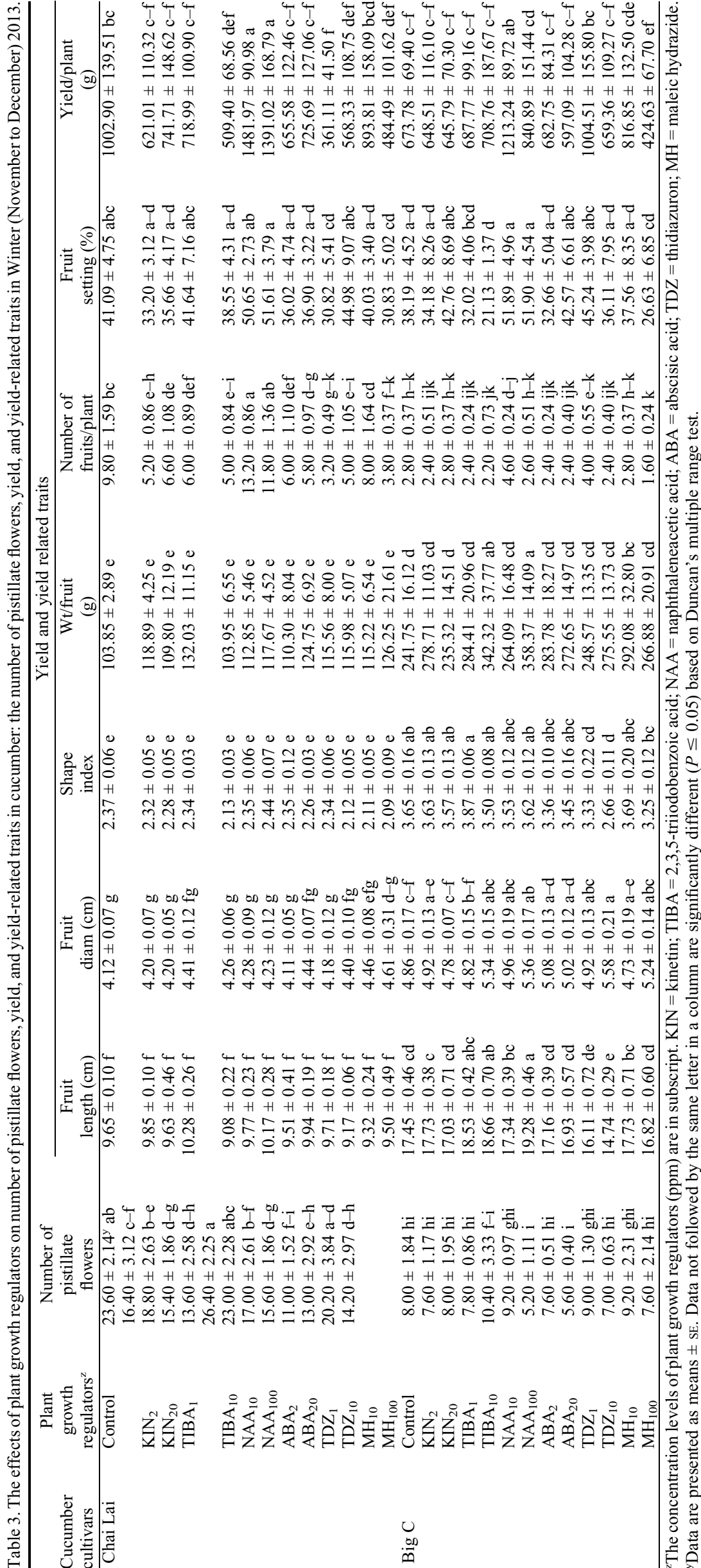

Many studies found that low humidity, longer photoperiod, and high temperature generally increased staminate flower numbers, whereas high humidity, shorter photoperiod, and low temperature increased pistillate flower production (Rahman, 1970). Ullah et al. (2011) observed a higher number of cucumber pistillate flowers in 2005 than in 2004, which might be attributed to modulation in endogenous PGR levels at a lower temperature in 2005. These findings are in agreement with our results indicating that the numbers of pistillate flowers in all treatments during winter (lower temperature) tended to be higher than those during summer, especially in 'Chai Lai' (Tables 3 and 4; Fig. 1).

Effects of plant growth regulators on yield-related traits and yield. Fruit length, fruit diameter, shape index, and fruit weight of cucumbers treated with various PGRs were not significantly different from control (distilled water) in 'Chai Lai' in either of the two seasons; however, these characteristics of 'Big C' varied during the two seasons. In the Winter of 2013, foliar application of 'Big C' with 10 ppm TIBA and 100 ppm NAA significantly increased the fruit length, whereas 10 ppm TDZ significantly decreased the fruit length compared with control. Application of $100 \mathrm{ppm}$ NAA also increased the fruit diameter significantly (Tables 3 and 4). Similarly, 100 ppm NAA increased the fruit diameter of bitter gourd significantly, possibly as a result of larger cell size induced by this PGR (Melissa and Nina, 2005). In addition, application of $10 \mathrm{ppm}$ TDZ also significantly increased the fruit diameter, leading to a significant reduction in shape index compared with control. With regard to fruit weight, it was found that application of $100 \mathrm{ppm}$ NAA gave the highest fruit weight (358.4 g) followed by $10 \mathrm{ppm}$ TIBA (342.3 g) and $10 \mathrm{ppm}$ MH (292.1 g). The fruit weights obtained from these three treatments were significantly higher than that of control $(241.8 \mathrm{~g})$. In the Summer of 2014, $10 \mathrm{ppm}$ TDZ also caused reduction in the fruit length of 'Big C'; however, many PGRs including 2 ppm KIN, 1 ppm TIBA, 10 ppm NAA, and 10 and $100 \mathrm{ppm} \mathrm{MH}$ significantly increased the fruit length compared with control. The increase in fruit length by $2 \mathrm{ppm}$ KIN, $1 \mathrm{ppm}$ TIBA, $10 \mathrm{ppm}$ NAA, and $10 \mathrm{ppm} \mathrm{MH}$ led to a significant increase in shape index compared with control (Tables 3 and 4). The effects of $\mathrm{MH}$ on fruit weight and length may result from the acceleration of cell enlargement and inhibition of cell division as was observed in melons (Kano, 2007). Similar to the Winter of 2013, 100 ppm NAA application in Summer 2014 gave the highest fruit weight $(251.8 \mathrm{~g})$, which was significantly higher than the control (196.4 g; Tables 3 and 4).

Our experimental data revealed that some PGRs including TIBA, NAA, and $\mathrm{MH}$ increased fruit size (fresh weight, fruit length and/or diameter) significantly in 'Big C' and were inclined to increase the fruit size in 'Chai Lai'. In cucumber, several studies reported that fruit weight from NAA foliar 


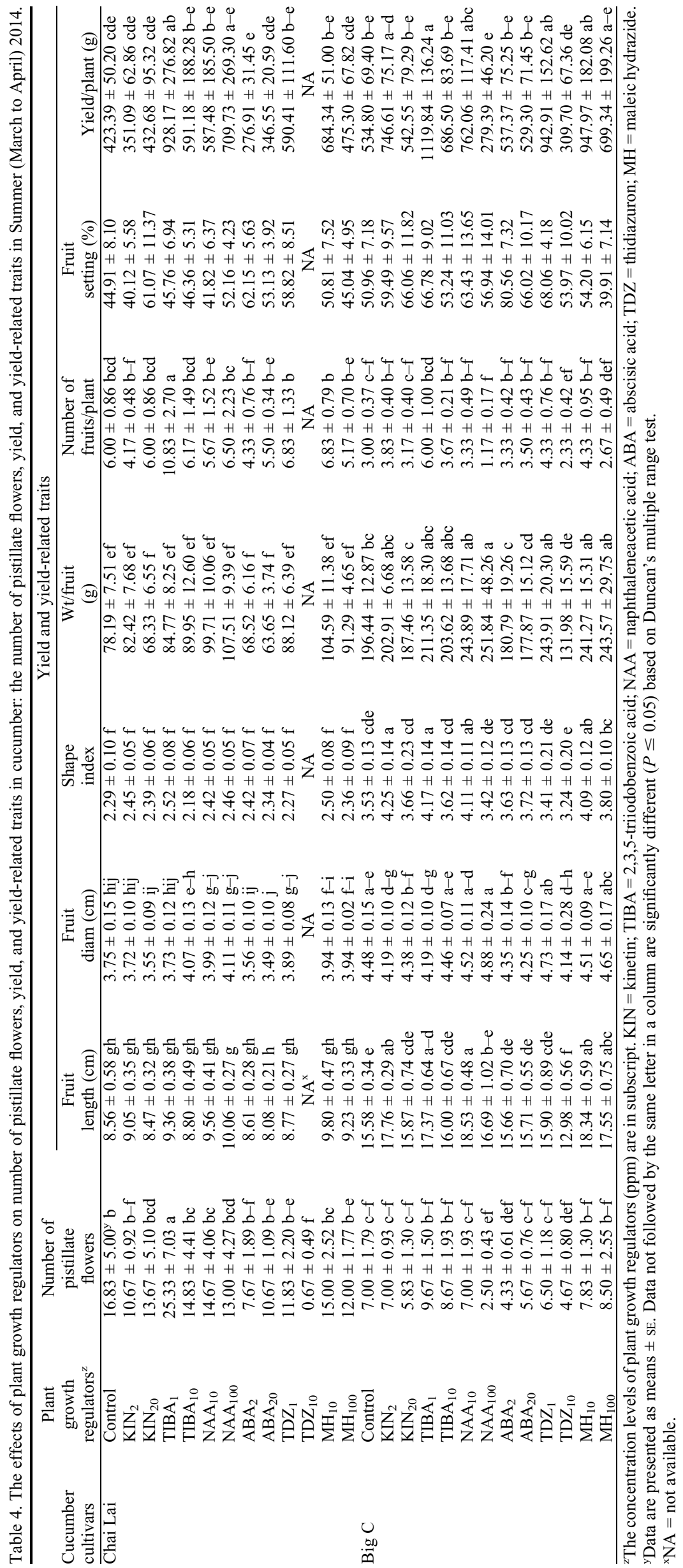

application was not significantly different in comparison with control (Jadav et al., 2010; Thappa et al., 2011), but the exogenous application of $\mathrm{MH}$ significantly increased the single fruit weight compared with the untreated control (Thappa et al., 2011; Ullah et al., 2011). These differences may reflect genotypic and/or environmental effects on cucumber fruit development in response to PGRs. To the best of our knowledge, this is the first report of TIBA effects on cucumber fruit size. Similar to cucumber, the highest fresh weight was obtained from $10 \mathrm{ppm}$ TIBA foliar application in bottle gourd (Rahman et al., 1992). Application of 50 to 200 ppm TIBA also gave a significant increase in the weight of fruits and the number of fruits in water melon (Gopalkrishnan and Choudhury, 1978). Increases in fruit size are the result of cell enlargement that is usually hormonally regulated. Auxins are known to be involved in plant cell division, cell elongation, and differentiation (Arteca, 1996). Therefore, applications of NAA and TIBA may alter endogenous auxin levels, thereby modifying fruit size.

The observation of yield production during the Winter season of 2013 showed that 10 ppm NAA application gave the highest yields/plant in both cultivars, which were significantly higher than control. In this treatment, there was a 1.5 -fold yield increase in comparison with control in 'Chai Lai' and a 1.8-fold increase in 'Big C', leading to higher gross income with $9 \%$ to $22 \%$ increase in net return. In 'Chai Lai', the application of NAA at a higher concentration (100 ppm) also significantly increased fruit yield 1.4-fold over control. The highest yield achieved with 10 ppm NAA application in 'Chai Lai' may stem from the significant increase in number of fruits/plant (1.3-fold over control). In 'Chai Lai', applications of $10 \mathrm{ppm}$ TIBA, 1 and $10 \mathrm{ppm}$ TDZ, and 100 ppm MH decreased yield significantly when compared with control, but yield of those treatments was statistically similar to control in 'Big C' (Table 3). These results were in agreement with some previous studies. In cucumber, Jadav et al. (2010) investigated various PGR effects on sex modification and yield of commercially grown cucumber cultivars and revealed that the 100 and 200 ppm NAA treatments gave a significantly higher yield (16.67 and $17.72 \mathrm{t} \cdot \mathrm{ha}^{-1}$ ) and an increase in the number of fruits, whereas the controls (without spray and water spray) produced the lowest yield (11.47 and $12.79 \mathrm{t} \cdot \mathrm{ha}^{-1}$, respectively). However, in long green cucumber, the yield-related traits including number of fruits/vine, fruit weight/vine, and fruit yield were not significantly affected by the applications of 50 and 100 ppm NAA (Thappa et al., 2011). In fluted pumpkin, the highest yield of $4.5 \mathrm{~kg} /$ vine was recorded for 200 ppm NAA application, which was significantly higher than that of control (2.9 kg/vine) (Sunny and Nwonuala, 2013). NAA spraying at $100 \mathrm{ppm}$ also tended to increase the total yield in watermelon, 
whereas all concentrations $(100,150$, and $200 \mathrm{ppm}$ ) of NAA spraying had no significant effect on the yield of cantaloupe in the Spring of 1968. Nevertheless, 100 ppm IAA treatment increased the total yield of cantaloupe (Rahman and Thompson, 1969).

In the Summer season of 2014, the highest yields were achieved with 1 ppm TIBA in both cultivars. In this treatment, yields were 2.2-fold and 2.1-fold significantly higher than control in 'Chai Lai' and 'Big C', respectively. These increases in yield were probably the result of the increase in the number of pistillate flowers and number of fruits/plant (Table 4). However, these increases in yield did not result in an increase in net return because of the high cost of TIBA, which is currently not available in agricultural grade in Thailand. Several experiments were conducted to evaluate the effect of TIBA on total yield in cucurbits including cucumber. Some of these studies reported that TIBA applications tended to increase yield in some plants, i.e., watermelon and cantaloupe. However, in cucumber, 25 ppm TIBA spray was found to decrease total yield (Rahman, 1970; Rahman and Thompson, 1969). Our study is the first to show that a low concentration of TIBA foliar application significantly increased yield in both cucumber cultivars in the Summer season of 2014. It is likely that the TIBA effects were season- and/or genotype-dependent and should be determined specifically for each genotype and environment. In this season, application of 10 ppm NAA also induced a higher yield (1.4-fold higher than control) in both cultivars; however, the differences were not significant when compared with the control. Moreover, 1 ppm TDZ and 10 ppm MH applications also tended to enhance yields in both cultivars. The different results of TIBA and NAA applications on many cucurbits including our results on two cucumber cultivars indicated that the effects of these PGRs on yield production depended on plant genotypes, types, and concentrations of PGRs as well as the environments.

Our results suggest that PGR responses on yield are environmentally variable in cucumber. Similarly, Rahman (1970) found that the effects of chemical regulators on cucumber yield (total number of fruits and weight) varied during Spring and Fall seasons in 1968. The effects of KIN application on marketable yield of 'Bodega' cucumber during the Spring-Summer and Fall-Winter season in 2004 were also different (Papadopoulos et al., 2006). Positive cucumber yield response to foliar application of $2.5 \mathrm{ppm}$ KIN was only observed in the Spring-Summer of 2004. In our study, treatment of both cucumber cultivars with both concentrations of KIN did not result in any significant increase in total yield both in winter and summer seasons (Tables 3 and 4). Likewise, the treatment of cytokinin-containing compounds [Cytozyme (Cytozyme, Inc., Salt Lake City, UT) and Cytex (Atlantic and Pacific Research, Inc., North Palm Beach, FL)] caused no significant change in the fruit yields of a cucumber inbred line (Staub et al., 1987).

Several studies indicated that multiple lateral branching can increase cucumber yield. Of all the characteristics evaluated (number of branches/plant, nodes/branch, pistillate nodes, and fruit set), Staub et al. (2008) found that only the number of branches/plant was consistently correlated with yield. We also found that application of 100 ppm NAA significantly increased the number of branches as well as the fruit yield of 'Chai Lai' in the Winter of 2013. Similarly, $1 \mathrm{ppm}$ TIBA increased the number of branches as well as the fruit yield in the Summer of 2014 (Tables 1-4). In both seasons, a positive correlation was observed between number of branches and yield. Number of nodes on main stem, pistillate flower numbers, and fruit numbers/plant appeared to be positively correlated with yield in our study. Besides, fruit weight was also significantly correlated with yield in the Summer of 2014 (Table 5). Synthetic auxins such as NAA have been shown to be the most effective in promoting set in fruits having multiple ovules such as strawberry, squash, fig (Arteca, 1996). In addition, Hidayatullah et al. (2009) reported that $\mathrm{MH}$ at 225 and $675 \mu \mathrm{M}$ proved most effective and could increase fruit set of 'Sialkot Selection' cucumber up to $20 \%$ when compared with control. Although our results showed that the application of all PGRs did not significantly affect percentages of fruit setting when compared with control, the application of NAA tended to increase the fruit setting of both cultivars during the Winter of 2013. Similarly, fruit set percentage of tomato plants, which were treated with $0.02 \%$ NAA and $1 \%$ calcium chloride, also significantly increased, possibly as a result of reduced flower drop (Abbasi et al., 2013). Nagargoje et al. (2007) also reported that the spray of $100 \mathrm{ppm}$ NAA at the $50 \%$ flowering stage of sapota reduced the flower drop and increased the fruit setting. It was suggested that spraying of NAA at the time of flowering prevents preharvest flower abscission by increasing the available auxin concentration at the critical phase of reproductive development (Alam and Khan, 2002). The synthetic auxins such as NAA and indole butyric acid were found to have a stronger inhibiting effect on flower abscission and decreased the sensitivity of the cells in the abscission zone to ethylene, a gaseous PGR involved in abscission of plant organs (Rungruchkanont, 2011). In addition, a significant correlation was observed between the percentage of fruit setting and yield in both seasons (Tables 3-5).

Effects of plant growth regulators on in vitro gynogenesis. ELSs and calli began to

Table 5. Correlation coefficients between vegetative growth, floral, and yield-related traits and yield of two cucumber cultivars in the Winter of 2013 and the Summer of 2014.

\begin{tabular}{lcc}
\hline & \multicolumn{2}{c}{ Yield/plant } \\
\cline { 2 - 3 } Vegetative growth, floral, and yield-related traits & Winter 2013 & Summer 2014 \\
\hline Number of branches & $0.416^{* z}$ & $0.598^{* *}$ \\
Number of nodes on main stem & $0.471^{* *}$ & $0.557^{* *}$ \\
Number of pistillate flowers & $0.526^{* *}$ & $0.345^{*}$ \\
Fruit setting & $0.698^{* *}$ & $0.437^{*}$ \\
Number of fruits/plant & $0.729^{* *}$ & $0.492^{* *}$ \\
Weight/fruit & -0.079 & $0.555^{* *}$ \\
\hline
\end{tabular}

appear on the surface of ovules at $\approx 1$ to 2 weeks after culture initiation. Table 6 shows that the highest percentages of the callus formation $(100 \%)$ were found in 'Chai Lai' after culturing on I7 medium after exogenous application of TIBA at 1 and $10 \mathrm{ppm}$, although these were not significantly different from control and other treatments. Application of KIN at 2 and $20 \mathrm{ppm}$ also tended to increase percentages of callus formation when cultured on $\mathrm{I} 7$ medium in this cultivar. However, the effects were not found in 'Big C' in which all treatments resulted in a relatively high percentages of callus formation, ranging from $83.33 \%$ to $100 \%$ (Table 6). Cytokinins appear to be necessary for plant cell division during tissue culture processes including callus proliferation and embryogenesis. A low concentration of cytokinin (typically 0.5 to $2.5 \mu \mathrm{M}$ ) is often added to media for the induction of embryogenic callus. Cytokinin has also been one of the important factors that helps to increase the frequencies of ELS formation (Van Staden et al., 2008). In our study, exogenous application of KIN at both 2 and $20 \mathrm{ppm}$ tended to enhance the callus formation in 'Chai Lai', and KIN at 20 ppm tended to increase the efficiencies of ELS formation in both cultivars. In 'Chai Lai', $2 \mathrm{ppm}$ KIN and $1 \mathrm{ppm}$ TIBA also tended to enhance ELS formation when cultured on I7 medium, although the effects were not statistically significant when compared with control. In this cultivar, maximum ELS formation $(100 \%)$ was observed when treated with 2 ppm KIN and cultured on $\mathrm{I} 7$ medium. In 'Big C', exogenous application of $20 \mathrm{ppm}$ KIN and 1 ppm TIBA also gave maximum ELS formation $(83.33 \%$ and $84.72 \%$, respectively) when cultured on 17 medium. The number of ELSs/piece in these treatments was also comparable to control and other treatments. By contrast, TIBA at a high concentration $(10 \mathrm{ppm})$ tended to reduce the percentages of ELS formation and the number of ELSs/piece in both cultivars. These results suggest a negative dose-response of ELS formation potential to TIBA above a certain threshold concentration; a low concentration of TIBA tended to enhance ELS formation, whereas a high concentration tended to inhibit the formation in both cucumber cultivars (Table 6). Polar auxin transport has long been postulated to play a central role in plant embryogenesis. The process of somatic embryogenesis is often initiated in media containing high levels of auxins, but embryos usually do not develop further until 
Table 6. The percentages of callus formation, ELS formation, and number of ELSs/piece from unpollinated ovaries of cucumber after different exogenous plant growth regulator applications on various induction media.

\begin{tabular}{|c|c|c|c|c|c|}
\hline $\begin{array}{l}\text { Cucumber } \\
\text { cultivars }\end{array}$ & $\begin{array}{l}\text { Plant growth } \\
\text { regulators }^{\mathrm{z}}\end{array}$ & $\begin{array}{c}\text { Induction } \\
\text { media }\end{array}$ & $\begin{array}{c}\text { Callus } \\
\text { formation }(\%)\end{array}$ & ELS formation (\%) & $\begin{array}{l}\text { Number of } \\
\text { ELSs/piece }\end{array}$ \\
\hline \multirow[t]{15}{*}{ Chai Lai } & \multirow[t]{3}{*}{ Control } & $\mathrm{I} 2 \mathrm{G}$ & $71.21 \pm 8.13^{\mathrm{y}} \mathrm{abc}$ & $76.52 \pm 6.44 \mathrm{a}-\mathrm{e}$ & $20.81 \pm 1.79 \mathrm{abc}$ \\
\hline & & I7 & $76.67 \pm 10.00 \mathrm{abc}$ & $76.67 \pm 10.00 \mathrm{a}-\mathrm{e}$ & $22.00 \pm 2.81 \mathrm{ab}$ \\
\hline & & I9 & $71.21 \pm 12.12 \mathrm{abc}$ & $74.24 \pm 7.90 \mathrm{a}-\mathrm{e}$ & $24.06 \pm 2.57 \mathrm{a}$ \\
\hline & \multirow[t]{3}{*}{$\mathrm{KIN}_{2}$} & $\mathrm{I} 2 \mathrm{G}$ & $68.06 \pm 10.82 \mathrm{abc}$ & $80.83 \pm 5.14 \mathrm{a}-\mathrm{d}$ & $17.62 \pm 2.15 \mathrm{a}-\mathrm{d}$ \\
\hline & & I7 & $88.89 \pm 7.03 \mathrm{abc}$ & $100.00 \pm 0.00 \mathrm{a}$ & $22.06 \pm 3.24 \mathrm{ab}$ \\
\hline & & I9 & $69.45 \pm 12.11 \mathrm{abc}$ & $73.89 \pm 4.12 \mathrm{a}-\mathrm{e}$ & $24.56 \pm 3.96 \mathrm{a}$ \\
\hline & \multirow[t]{3}{*}{$\mathrm{KIN}_{20}$} & $\mathrm{I} 2 \mathrm{G}$ & $69.61 \pm 8.95 \mathrm{abc}$ & $60.79 \pm 5.88 \mathrm{c}-\mathrm{f}$ & $17.56 \pm 1.85 \mathrm{a}-\mathrm{d}$ \\
\hline & & I7 & $85.71 \pm 7.65 \mathrm{abc}$ & $95.24 \pm 3.07 \mathrm{ab}$ & $24.64 \pm 2.26 \mathrm{a}$ \\
\hline & & I9 & $78.13 \pm 6.76 \mathrm{abc}$ & $58.13 \pm 6.62 \mathrm{def}$ & $20.72 \pm 2.24 \mathrm{abc}$ \\
\hline & \multirow[t]{3}{*}{$\mathrm{TIBA}_{1}$} & $\mathrm{I} 2 \mathrm{G}$ & $80.39 \pm 7.73 \mathrm{abc}$ & $62.74 \pm 5.63 \mathrm{c}-\mathrm{f}$ & $21.08 \pm 1.98 \mathrm{abc}$ \\
\hline & & $\mathrm{I} 7$ & $100.00 \pm 0.00 \mathrm{a}$ & $92.59 \pm 2.94 \mathrm{abc}$ & $22.47 \pm 0.77 \mathrm{ab}$ \\
\hline & & I9 & $65.97 \pm 7.57 \mathrm{bc}$ & $59.03 \pm 7.91 \mathrm{def}$ & $20.76 \pm 3.88 \mathrm{abc}$ \\
\hline & \multirow[t]{3}{*}{$\mathrm{TIBA}_{10}$} & $\mathrm{I} 2 \mathrm{G}$ & $63.64 \pm 9.49 \mathrm{c}$ & $54.54 \pm 8.73 \mathrm{def}$ & $20.23 \pm 4.56 \mathrm{a}-\mathrm{d}$ \\
\hline & & I7 & $100.00 \pm 0.00 \mathrm{a}$ & $66.67 \pm 8.91 \mathrm{~b}-\mathrm{e}$ & $13.88 \pm 2.38 \mathrm{a}-\mathrm{d}$ \\
\hline & & I9 & $76.19 \pm 8.86 \mathrm{abc}$ & $48.57 \pm 6.13$ ef & $11.04 \pm 1.13 \mathrm{bcd}$ \\
\hline \multirow[t]{15}{*}{ Big C } & \multirow[t]{3}{*}{ Control } & $\mathrm{I} 2 \mathrm{G}$ & $96.97 \pm 3.03 \mathrm{ab}$ & $73.64 \pm 9.73 \mathrm{a}-\mathrm{e}$ & $20.27 \pm 2.47 \mathrm{a}-\mathrm{d}$ \\
\hline & & $\mathrm{I} 7$ & $100.00 \pm 0.00 \mathrm{a}$ & $70.84 \pm 19.69 \mathrm{a}-\mathrm{e}$ & $19.71 \pm 5.60 \mathrm{a}-\mathrm{d}$ \\
\hline & & I9 & $92.59 \pm 7.41 \mathrm{abc}$ & $82.54 \pm 7.83 \mathrm{a}-\mathrm{d}$ & $19.09 \pm 2.76 \mathrm{a}-\mathrm{d}$ \\
\hline & \multirow[t]{3}{*}{$\mathrm{KIN}_{2}$} & $\mathrm{I} 2 \mathrm{G}$ & $95.83 \pm 4.17 \mathrm{abc}$ & $77.08 \pm 10.42 \mathrm{a}-\mathrm{e}$ & $13.03 \pm 2.38 \mathrm{a}-\mathrm{d}$ \\
\hline & & I7 & $100.00 \pm 0.00 \mathrm{a}$ & $66.67 \pm 16.67 \mathrm{~b}-\mathrm{e}$ & $14.92 \pm 1.52 \mathrm{a}-\mathrm{d}$ \\
\hline & & I9 & $83.33 \pm 10.54 \mathrm{abc}$ & $71.33 \pm 8.67 \mathrm{a}-\mathrm{e}$ & $16.95 \pm 5.43 \mathrm{a}-\mathrm{d}$ \\
\hline & \multirow[t]{3}{*}{$\mathrm{KIN}_{20}$} & $\mathrm{I} 2 \mathrm{G}$ & $96.88 \pm 3.13 \mathrm{ab}$ & $60.42 \pm 16.65 \mathrm{c}-\mathrm{f}$ & $8.83 \pm 1.74 \mathrm{~d}$ \\
\hline & & $\mathrm{I} 7$ & $96.67 \pm 3.33 \mathrm{ab}$ & $83.33 \pm 12.91 \mathrm{a}-\mathrm{d}$ & $17.38 \pm 1.82 \mathrm{a}-\mathrm{d}$ \\
\hline & & I9 & $90.48 \pm 7.14 \mathrm{abc}$ & $80.95 \pm 7.65 \mathrm{a}-\mathrm{d}$ & $22.21 \pm 4.43 \mathrm{ab}$ \\
\hline & \multirow[t]{3}{*}{$\mathrm{TIBA}_{1}$} & $\mathrm{I} 2 \mathrm{G}$ & $96.15 \pm 2.77 \mathrm{ab}$ & $61.79 \pm 10.18 \mathrm{c}-\mathrm{f}$ & $13.65 \pm 2.59 \mathrm{a}-\mathrm{d}$ \\
\hline & & $\mathrm{I} 7$ & $100.00 \pm 0.00 \mathrm{a}$ & $84.72 \pm 5.45 \mathrm{a}-\mathrm{d}$ & $17.66 \pm 2.86 \mathrm{a}-\mathrm{d}$ \\
\hline & & I9 & $91.03 \pm 4.85 \mathrm{abc}$ & $62.56 \pm 9.08 \mathrm{c}-\mathrm{f}$ & $13.38 \pm 4.28 \mathrm{a}-\mathrm{d}$ \\
\hline & \multirow[t]{3}{*}{$\mathrm{TIBA}_{10}$} & $\mathrm{I} 2 \mathrm{G}$ & $93.94 \pm 4.65 \mathrm{abc}$ & $32.56 \pm 7.15 \mathrm{f}$ & $11.11 \pm 1.67 \mathrm{bcd}$ \\
\hline & & I7 & $100.00 \pm 0.00 \mathrm{a}$ & $58.33 \pm 10.32 \mathrm{def}$ & $9.47 \pm 2.36 \mathrm{~cd}$ \\
\hline & & I9 & $95.83 \pm 4.17 \mathrm{abc}$ & $47.92 \pm 6.63$ ef & $14.91 \pm 1.79 \mathrm{a}-\mathrm{d}$ \\
\hline
\end{tabular}

${ }^{\mathrm{z}}$ The concentration levels of plant growth regulators $(\mathrm{ppm})$ are in subscript. $\mathrm{KIN}=$ kinetin; TIBA $=2,3,5$ triiodobenzoic acid.

${ }^{y}$ Data are presented as means \pm SE. Data not followed by the same letter in a column are significantly different $(P \leq 0.05)$ based on Duncan's multiple range test.

ELS $=$ embryo-like structure.

the auxin concentration is reduced (Machakova et al., 2008). Therefore, TIBA or other auxin transport inhibitors (i.e., N-1-naphthylphthalamic acid), which inhibits polar auxin transport, may enhance ELS development. Similarly, Lazzeri et al. (1988) discovered that the number of soybean embryos was reduced if the concentration ratio of auxin:sucrose was high or vice versa. Nevertheless, TIBA at 1 , 2,4 , and $8 \mu \mathrm{M}$ suppressed embryo formation in the cell culture of Elutherococcus senticosus (Choi et al., 2001).

A comparison between two cucumber cultivars showed that 'Big C' had higher callus formation abilities than 'Chai Lai', but ELS formation efficiencies of both cultivars were similar (Table 6). The variable responses of unpollinated ovary/ovule culture among different genotypes have been observed in cucumber; for example, Suprunova and Shmykova (2008) reported that of 10 cultivars tested, only the embryo sac of 'Gordion' resulted in increased volume when the unpollinated ovules were cultured on induction medium with TDZ. However, Diao et al. (2009) reported that embryo formation frequencies of six cucumber cultivars were similar.

Our results indicated that induction media significantly affected gynogenesis in cucumber. In control (without exogenous application of PGRs before ovary culture), medium, with only $0.04 \mathrm{ppm} \mathrm{TDZ,} \mathrm{was} \mathrm{found}$ to be the best medium for ELS/callus formations in both cultivars (Table 6). I7 induction medium was reported to achieve the highest embryo formation frequencies in all six hybrid cucumber cultivars (Diao et al., 2009). Similarly, Li et al. (2013) showed that the frequencies of induced embryos in Chinese long cucumber inbred lines were significantly higher with the induction media supplemented with 0.03 to $0.07 \mathrm{ppm}$ TDZ. Our results confirmed that the optimal level of TDZ is crucial for embryo induction in cucumber unpollinated ovary culture.

The percentages of ELS formation depended on genotypes of donor plants, induction media, and exogenous application of PGRs. In 'Chai Lai', the highest ELS formation potential was achieved when 2 ppm KIN was applied during floral development and cultured on I7 medium, whereas in 'Big C', 1 ppm TIBA application onto developing flowers resulted in the highest percentage of ELS formation on 17 medium (Table 6).

In conclusion, the exogenous application of PGRs influenced vegetative growth, floral and yield-related traits, yield as well as in vitro gynogenesis in Thai cucumber cultivars. The successful PGR applications depended on many factors including cucumber genotypes, induction media, growing seasons, types of PGRs, and the optimal concentrations used. These factors may be manipulated to induce ELS formation for efficient production of $\mathrm{H} / \mathrm{DH}$ cucumbers and/or to increase yield of commercial cucumber cultivars.

\section{Literature Cited}

comparable callus formation efficiencies were observed among the three induction media (I2G, I7, and I9) in both cucumber cultivars. In 'Chai Lai', ELS formation efficiencies were also comparable among the three induction media; however, I9 tended to be more efficient than $\mathrm{I} 2 \mathrm{G}$ and $\mathrm{I} 7$ in 'Big C', although the difference was not significant (Table 6). These results suggest that the addition of $\mathrm{Gln}, \mathrm{CH}$, and TRIA in 19 may be beneficial for cucumber gynogenesis in some cultivars. In anther culture, the addition of organic compounds such as $\mathrm{Gln}, \mathrm{CH}$, etc., into the medium has been reported to increase the efficiency of microspore embryogenesis (Germaná, 2011). In cucumber, the addition of $0.8 \mathrm{~g} \cdot \mathrm{L}^{-1} \mathrm{Gln}$ to the induction medium supplemented with various PGRs also increased the yield of $\mathrm{H}$ cucumber plants from anther culture (Suprunova and Shmykova, 2008). In addition, Hangarter and Ries (1978) reported that TRIA increased growth and weight of $\mathrm{H}$ tobacco, tomato, potato, bean, and barley cell culture. Further study indicated that the increase in growth of tobacco callus in response to TRIA seemed to result from an increase in cell numbers. Nevertheless, when KIN or TIBA were exogenously applied before ovary culture, addition of these compounds to the induction media tended to reduce callus and ELS formation efficiencies in both cucumber cultivars. In these cases, I7 induction
Abbasi, N.A., L. Zafar, H.A. Khan, and A.A. Qureshi. 2013. Effect of naphthalene acetic acid and calcium chloride application on nutrient uptake, growth, yield and post harvest performance of tomato fruit. Pak. J. Bot. 45:1581-1587.

Alam, S.M. and M.A. Khan. 2002. Fruit yield of tomato as affected by NAA spray. Asian J. Plant Sci. 1:24.

Amarante, C.V.T. do, P.R. Ernani, L.E.B. Blum, and C.A. Megguer. 2002. Thidiazuron effects on shoot growth, return bloom, fruit set and nutrition of apples. Pesq. Agropec. Bras., Brasília 37:1365-1371.

Arteca, R.N. 1996. Plant growth substances: Principles and applications. Chapman and Hall, London, UK.

Barciszewski, J., G. Siboska, S.I.S. Rattan, and B.F.C. Clark. 2000. Occurrence, biosynthesis and properties of kinetin ( $\mathrm{N}^{6}$-furfuryladenine). Plant Growth Regulat. 32:257-265.

Bhojwani, S.S. and M.K. Razdan. 1996. Plant tissue culture: Theory and practice, a revised edition. Elsevier Science BV, Amsterdam, The Netherlands.

Chen, J.F., L. Cui, A.A. Malik, and K.G. Mbira. 2011. In vitro haploid and dihaploid production via unfertilized ovule culture. Plant Cell Tissue Organ Cult. 104:311-319.

Choi, Y.E., M. Katsumi, and H. Sano. 2001 Triiodobenzoic acid, an auxin polar transport inhibitor, suppresses somatic embryo formation and post embryonic shoot/root development in Elutherococcus senticosus. Plant Sci. 160:1183-1190. 
Choudhury, B. and N. Singh. 1970. Chemical sex modification and its effect on fruiting of cucumber (Cucumis sativus L.) at three locations. Indian J. Hort. 27:180-183.

Cooke, T.J., R.H. Racusen, and J.D. Cohen. 1993. The role of auxin in plant embryogenesis. Plant Cell 5:1494-1495.

Diao, W.P., Y.Y. Jia, H. Song, X.Q. Zhang, Q.F. Lou, and J.F. Chen. 2009. Efficient embryo induction in cucumber ovary culture and homozygous identification of the regenerants using SSR markers. Sci. Hort. 119:246-251.

El-Ghamriny, E.A., N. Singh, and V.K. Verma. 1988. Anatomical studies of sex expression in cucumber (Cucumis sativas L.) following hormonal application. Curr. Sci. 57:263-264.

FAOSTAT. 2014. Crops: Final 2012 data. 1 Dec. 2014. <http://faostat.fao.org/site/567/ default.aspx\#ancor $>$.

Germaná, M.A. 2011. Anther culture for haploid and doubled haploid production. Plant Cell Tissue Organ Cult. 104:283-300.

Gémesné Juhász, A., P. Balogh, A. Ferenczy, and Z. Kristóf. 2002. Effect of optimal stage of female gametophyte and heat treatment on in vitro gynogenesis induction in cucumber ( $\mathrm{Cucu}$ mis sativas L.). Plant Cell Rpt. 21:105-111.

Gémesné Juhász, A., G. Venczel, and P. Balogh. 1997. Haploid plant induction in zucchini (Cucurbita pepo L. convar. giromontiina DUCH) and in cucumber (Cucumis sativas L.) lines through in vitro gynogenesis, p. 623-624. In: Altman, A. and M. Ziv (eds.). Hortic. Biotech. In Vitro Cult. Breed. Acta Hort. 447.

Gopalkrishnan, P.K. and B. Choudhury. 1978. Effect of plant growth regulators sprays on modification of sex ratio, fruit set and development in water melon (Citrullus lanatus Thunb. Mansf.). Indian J. Hort. 35:235-241.

Guo, B., B.H. Abbasi, A. Zeb, L.L. Xu, and Y.H. Wei. 2011. Thidiazuron: A multi-dimensional plant growth regulator. Afr. J. Biotechnol. 10:8984-9000.

Hangarter, R. and S.K. Ries. 1978. Effect of triacontanol on plant cell cultures in vitro. Plant Physiol. 61:855-857.

Hidayatullah, A. Bano, and K.M. Khokhar. 2009. Sex expression and level of phytohormones in monoecious cucumber as affected by plant growth regulators. Sarhad J. Agr. 25:173-177.

Jadav, R.G., T.V. Patel, A.B. Parmar, and M.Y. Saiyad. 2010. Sex modification of cucumber vegetable through PGRs. PRAJÑ̃̃. 18:13-14.

Kano, Y. 2007. Effects of maleic hydrazide treatment on the size and number of cells and sugar accumulation in the fruit of melon (Cucumis melo L.). HortScience 42:1357-1360.

Krishnamoorthy, H.N. 1981. Plant growth substances. Tata McGraw-Hill, New Delhi, India.

Lazzeri, P.A., D.F. Hildebrand, J. Sunega, E.G. Williams, and G.B. Collins. 1988. Soybean somatic embryogenesis: Interactions between sucrose and auxin. Plant Cell Rpt. 7:517-520.

Levesque, R. SPSS Inc. 2006. SPSS programming and data management. 2nd Ed. SPSS Inc., Chicago, IL.

Li, J.W., S.W. Si, J.Y. Cheng, J.X. Li, and J.Q. Liu. 2013. Thidiazuron and silver nitrate enhanced gynogenesis of unfertilized ovule cultures of Cucumis sativus. Biol. Plant. 57:164-168.

Machakova, I., E. Zazimalova, and E.F. George. 2008. Plant growth regulators I: Introduction; auxins, their analogues and inhibitors, p. 175204. In: Hall, M.A., G.J.D. Klerk, and E.F George (eds.). Plant propagation by tissue culture. 3rd Ed. Springer, Dordrecht, The Netherlands.

Meexaewkunchorn, P. 1995. Using naphthaleneacetic acid (NAA), ethephon and gibberellic acid for increasing pistillate flowers in cucumber. Proc. 33rd Kaset. Univ. Annu. Conf. Plants, Bangkok, Thailand, 30 Jan. to 1 Feb. 1995.

Melissa, F.T. and M.C. Nina. 2005. Effects of naphthaleneacetic acid (NAA) and gibberellic acid $\left(\mathrm{GA}_{3}\right)$ on fruit morphology, parthenocarpy, alkaloid and chlorophyll content in bitter gourd (Momordica charantia L. 'Makiling'). Philippines Agr. Sci. 88:35-39.

Mia, M.A.B., M.S. Islam, and Z.H. Shamsuddin 2014. Altered sex expression by plant growth regulators: An overview in medicinal vegetable bitter gourd (Momordica charantia L.). J. Med. Plants Res. 8:361-367.

Moqbeli, E., Gh. Peyvast, Y. Hamidoghli, and J.A. Olfati. 2013. In vitro cucumber haploids line generation in several new cultivars. AsPac J. Mol. Biol. Biotechnol. 21:18-25.

Murashige, T. and F. Skoog. 1962. A revised medium for rapid growth and bioassays with tobacco cultures. Physiol. Plant. 15:473-497.

Nagargoje, B.S., D.B. Kachave, S.B. Shinde, and K.M. Jadhav. 2007. Effect of NAA on flower drop, fruit set, fruit drop and fruit retention in sapota variety Kalipatti. J. Soils and Crops. 17:173-175.

Papadopoulos, A.P., U. Saha, X. Hao, and S. Khosla 2006. Response of rockwool-grown greenhouse cucumber, tomato, and pepper to kinetin foliar sprays. HortTechnology 16:493-501.

Rahman, M.A. 1970. Modification of flowering, sex expression and fruiting of selected cucurbits by growth-regulating chemicals. PhD diss., Univ. of Florida, Gainesville, FL.

Rahman, M.A., A.N.M. Alamgir, and M.A.A. Khan. 1992. Effect of foliar application of IAA, $\mathrm{GA}_{3}$, TIBA and boron on growth, sex expression and yield of bottle gourd [Lagenaria siceraria (Mol.) Standl.]. Trop. Agr. Res. 4:55-65.

Rahman, M.A. and B.D. Thompson. 1969. Effects of some growth regulating chemicals on earliness and total yield of cantaloupe and watermelon. Fla. State Hort. Soc. 82:125-128.
Reed, S.M. 2005. Haploid culture, p. 225-234. In: Trigiano, R.N. and D.J. Gray (eds.). Plant development and biotechnology. CRC Press, Boca Raton, FL.

Rungruchkanont, K. 2011. Auxins and cytokinins regulate abscission and physiological changes of flowers in cut Dendrobium cv. Eiskul inflorescences. Sci. J. UBU. 2:1-11.

Sampaokaew, S., C. Pongsupamit, P. Pooprompan, and N. Rungruangsri. 2009. Effect of plant growth regulators on growth and development in ovule of Cucumis sativus L. Agr. Sci. J. 40:235-238

Smulders, M.J.M., A.F. Croes, and G.J. Wullems. 1998. Polar transport of 1-naphthaleneacetic acid determines the distribution of flower buds on explants of tobacco. Plant Physiol. 88:752-756.

Staub, J.E., M.D. Robbins, and T.C. Wehner. 2008. Cucumber, p. 241-282. In: Prohens, J. and F. Nuez (eds.). Vegetable I: Asteraceae, Brassicaceae, Chenopodicaceae, and Cucurbitaceae. Springer, New York, NY.

Staub, J.E., T.C. Wehner, and G.E. Tolla. 1987. Effect of treatment of cucumber seeds with growth regulators on emergence and yield of plants in the field. Acta Hort. 198:43-56.

Sunny, O.B. and A.I. Nwonuala. 2013. Prevalence of sexes and yield characteristics of hormone induced fluted pumpkin (Telfairia occidentalis Hook F.) in the humid tropics of southern Nigeria. Asian J. Agr. Sci. 5:32-35.

Suprunova, S. and N. Shmykova. 2008. In vitro induction of haploid plants in unpollinated ovules, anther and microspore culture of Cucumis sativus. Proc. IX EUCARPIA meeting Gen. Breed. Cucurbit., Avigon, France, 21-24 May 2008.

Tantasawat, P.A., A. Sorntip, O. Poolsawat, W. Chaowiset, and P. Pornbungkerd. 2015. Evaluation of factors affecting embryo-like structure and callus formation in unpollinated ovary culture of cucumber (Cucumis sativus). Intl. J. Agr. Biol. (in press).

Teixeira da Silva, J.A. 2012. Is BA (6-benzyladenine) BAP (6-benzylaminopurine)? Asian Australas. J. Plant Sci. Biotechnol. 6:121-124.

Thappa, M., S. Kumar, and R. Rafiq. 2011. Influence of plant growth regulators on morphological, floral and yield traits of cucumber (Cucumis sativus L.). Kasetsart J. (Nat. Sci.) 45:177-188.

Ullah, H., A. Bano, K.M. Khokhar, and T. Mahmood. 2011. Effect of seed soaking treatment with growth regulators on phytohormone level and sex modification in cucumber (Cucumis sativus L.). Afr. J. Plant Sci. 5:599-608.

Van Staden, J., E. Zazimalova, and E.F. George. 2008. Plant growth regulators II: Cytokinins, their analogues and antagonists, p. 205-226. In: Hall, M.A., G.J.D. Klerk, and E.F George (eds.). Plant propagation by tissue culture. 3rd Ed. Springer, Dordrecht, The Netherlands. 